Pregledni rad

UDK: 65.014:005.21

Datum primitka članka u uredništvo: 13. 4. 2018.

Datum slanja članka na recenziju: 17. 4. 2018.

Datum prihvaćanja članka za objavu: 5. 6. 2018.

Ana Krajnović, mag. oec. *

\title{
INSTITUCIONALNA TEORIJA I IZOMORFIZAM: RAZVOJ I DOPRINOS U MENADŽERSKIM ZNANOSTIMA
}

\author{
INSTITUTIONAL THEORY AND ISOMORPHISM: \\ DEVELOPMENT AND CONTRIBUTION \\ TO MANAGERIAL SCIENCES
}

\begin{abstract}
SAŽETAK: Inozemna, ali uglavnom domaća literatura, nudi oskudan pregled institucionalne teorije i institucionalnog izomorfizma. Ovaj pregledni rad će pridonijeti razjašnjavanju koncepta koji je nepravedno zanemaren, ali njegova važnost u poslovnoj praksi je nepobitna. Institucionalna teorija, i njezin ključni argument institucionalni izomorfizam, relativno je mlada teorijska perspektiva koja pruža razumijevanje poslovnih procesa kroz formirane strukture i poslovne prakse suvremenih organizacija s ciljem postizanja legitimnosti, a koje druge teorije ne nude. Stvaranjem konstrukta društvene stvarnosti oblikuje se obrazac ponašanja unutar organizacijskog polja kojeg organizacije prihvaćaju kao jedino pravilno i poželjno ponašanje entiteta unutar tog polja; krajnji cilj je postizanje i održavanje legitimnosti. Institucionalna teorija sugerira da se organizacije koje djeluju unutar iste industrijske grane ili organizacijskog polja prilagođavaju istim organizacijskim strukturama, ponašanjima i aktivnostima. Iako institucionalna teorija i dalje čeka prodor u relevantnu menadžersku literaturu, konceptualno pristup ima značajan doprinos pri razumijevanju organizacijske dinamike. Istraživanja temeljena na racionalističkim objašnjenjima organizacijskog ponašanja preusmjerena su prema prepoznavanju da su organizacijsko ponašanje i organizacijski procesi dio kulturnoga i političkoga konteksta.
\end{abstract}

KLJUČNE RIJEČI: institucionalna teorija, institucionalni izomorfizam, strateško upravljanje.

ABSTRACT: Both foreign but mainly domestic literature, offers exiguous review regarding institutional theory and institutional isomorphism. This overview will contribute to the clarification of the concept that is unfairly neglected but its relevance in business

Ana Krajnović, mag. oec., Privredna banka Zagreb d.d., Radnička cesta 50, 10000 Zagreb, e-mail: ana_krajnovich@hotmail.com. 
practice is irrefutable. Institutional theory and its key argument institutional isomorphism is a relatively young theoretical perspective that enables understanding business processes through the structures and performance of modern organizations in order to achieve legitimacy that other theories do not offer. By creating a construct of social reality, it is formed a pattern of behaviour within the organizational field that companies accept as the only proper and desirable behaviour of entities within that field; the ultimate goal is to achieve and maintain legitimacy. The institutional theory suggests that organizations operating within the same industrial branch or organizational field tend to adapt the same structures, behaviours and activities. Although institutional theory is still awaiting its penetration into relevant managerial literature, this approach conceptually has significant contribution when understanding the organizational dynamics. Research based on rational explanation of organizational behaviour has been redirected to the recognition that organizational behaviour and organizational processes are part of the cultural and political context.

KEY WORDS: institutional theory, institutional isomorphism, strategic management.

\section{UVOD}

Institucionalna teorija predstavlja teorijski okvir koji u prvome redu analizira sociološki aspekt organizacijskog ponašanja. Isto je, pretpostavlja se, formirano od strane institucija kroz pravila, poslovnu praksu i strukturu koji u biti usmjeravaju i oblikuju organizacijsko ponašanje. Razumijevanje organizacijskog ponašanja i organizacijske promjene posebno je važno za razvoj novih (institucionalnih) pristupa i razumijevanje formalnih organizacijskih struktura. Usvojeni konvencionalni teorijski pristupi poput neoklasične ekonomije i organizacijske teorije nisu pružili valjan i konkretan okvir koji bi omogućio konceptualizaciju organizacijskog ponašanja i organizacijske promjene iz formalne perspektive (Scott, 2008.). Institucionalnu teoriju obilježavaju uvjeti u okruženju u kojemu organizacije djeluju i njihov utjecaj na iste. Ograničenja koja se postavljaju utječu na kontekstualno oblikovanje poželjnoga ponašanja.

Znanstveni doprinos ovoga rada jasno se ogleda u dosad neistraženom području discipline strateškog menadžmenta. Teorijski doprinos vidljiv je iz pregleda postojećih teorijskih i nekolicine empirijskih istraživanja povezanih iz područja strateškog menadžmenta, institucionalne teorije organizacije i odlučivanja.

\section{OD “STAROG” DO “NOVOG” INSTITUCIONALIZMA}

Literatura koja prati razvoj i sazrijevanje ove teorije nudi razdiobu institucionalne teorije na stari (klasični) i novi (neo)institucionalizam. Početke institucionalne teorije pronalazimo među politolozima i sociolozima koji su proučavali kakav utjecaj imaju primarno političke institucije na kreiranje kolektivnog obrasca ponašanja (Hirsch, 1997.).

Legalizam kao početna premisa starog institucionalizma postavlja zakon kao središnji element u upravljanju društvenog poretka. Zakon i regulatorni okvir predstavlja glavni način kojime vlada neke države može utjecati na ponašanje svojih građana. Strukturalizam se nameće kao druga važna pretpostavka koja je objašnjavala kako je zaista struktura ta 
koja određuje ponašanje i sputava aktere u pokušajima bilo kakve reforme unutar usvojenog sustava. Teoretičari starog institucionalizma imali su tendenciju korištenja povijesne dimenzije u svojim analizama. Ne čudi, obzirom na to kako se svaki suvremeni politički sustav razvio tijekom vremena i dio je socioekonomskog i kulturološkog konteksta. Političko djelovanje moglo se razumjeti isključivo ako se razumije razvojni put koji je doveo do konačnog djelovanja. Posljednja karakteristika klasičnog institucionalizma je normativna analiza koja sagledava normativne elemente poput normi i društvenih vrijednosti, iako, prema klasičnim institucionalistima njihovo razlikovanje se negira i ne prihvaća (Peters, 2007.).

Najutjecajnija ličnost "starog" institucionalizma jest Thorstein Bunde Veblen koji kritizira neoklasičnu školu ekonomije zbog "manjkavog poimanja ljudske prirode" (Veblen, 1899.) te stavlja naglasak na tehnološku transformaciju kao i način na koji uvjeti u okruženju oblikuju konačnu akciju. Veblen je promatrao institucionalnu teoriju kao kumulativni prikaz institucionalne promjene i utjecaja novih tehnologija, a institucije nisu promatrane isključivo kao ograničenja akcije pojedinaca već su općeprihvaćeni načini ponašanja i razmišljanja (Rutherford, 2001.). Doprinos ovoga američkog sociologa i ekonomista značajan je u ekonomskim znanostima gdje je kroz svoj najpoznatiji koncept ,vidljive potrošnje“ utjecao na razumijevanje korporativnih financija te međuodnosa vlasništva i kontrolu takvih organizacija kao i kreiranje profitno orijentiranih strategija (Veblen, 1899.).

Temeljne pretpostavke klasičnog institucionalizma u vidu kontinuiranih strukturalnih promjena cjelokupnog ekonomskog sistema, a kojega nameću institucije temelj su za izgradnju institucionalne teorije kakva je danas. Sedamdesetih i osamdesetih godina dvadesetoga stoljeća interes za institucionalnu teoriju ponovno je zaživio kroz zapažene radove autora Meyera i Rowana (1977.), Marcha i Olsena (1984.) i onaj mnogo poznatiji DiMaggia i Powella (1983.). Novi institucionalizam javio se prije svega kao reakcija na bihevioralnu teoriju koja društveno djelovanje objašnjava naturalistički, to jest, gleda ponašanje pojedinca i ljudsko djelovanje kao razumnog bića koji teži stjecanju maksimalne koristi uz najpovoljniji odnos koristi i troškova (Lalić Novak, 2014.). Fokus je stavljen na objašnjenje institucija kao dinamičke konstrukte (a ne statične), a u obzir uzima i, dosad zanemarene, neformalne institucije. Meyer i Rowan (1977.) u svome radu spominju kako organizacije djeluju u institucionaliziranom kontekstu kojeg obilježavaju različite profesije, poslovne politike i programi te ih shodno tome organizacije integriraju u svoje poslovno okruženje. Specifičnost ovakvog načina konteksta ogleda se u tome što isti poprima ceremonijalni karakter; smatra se da je ovakvo prihvaćanje okruženja jedino ispravno i racionalno (Meyer, Rowan, 1977.). U svome radu, pružili su pet dimenzija na kojima se temelje ključne pretpostavke novog poimanja ove teorije: kontekstualizam, redukcionizam, utilitarizam, funkcionalizam i instrumentalizam.

Nadalje, kao najsnažniji argument institucionalne teorije ističe se kako je ponašanje i funkcioniranje organizacija u industrijskoj grani nametnuto od strane institucija, a ne samog tržišta (Meyer, Rowan 1997.). Od organizacije se očekuje da dokaže svoju legitimnost kako bi ostvarila pravo na korištenje i angažiranje resursa. Legitimnost se percipira kao poželjna akcija jednog entiteta unutar okvira društvenih vrijednosti, normi vjerovanja i definicija (Scott, 2001.). Obzirom da su obrasci društveno prihvatljivog ponašanja definirani okolinom (Tipurić, 2014. prema Meyer i Rowan, 1977.) akteri donose odluke koje su društveno prihvatljive (ne nužno racionalne).

Korak naprijed u "novom" institucionalizmu učinjen je u proširenoj definiciji i poimanju samih institucija. Dok je tradicionalni institucionalizam isključivo promatrao snagu 
i formalnu strukturu koju institucije imaju, novi institucionalizam promatra učinak istih na proces donošenja odluka (Nugent i Campos, 1999.). Šira perspektiva institucija uključuje veći raspon poslovnih praksi i procedura, intraorganizacijskih odnosa, ali i formalnih i neformalnih struktura; neformalne institucije nisu standardizirane niti formalizirane; one predstavljaju prešutne društvene konvencije i pravila ponašanja (North, 2003.).

Herbert Simon je, istražujući mikroekonomske probleme poduzeća, zaključio da su kognitivni kapaciteti za inteligentno prikupljanje i obradu informacija (a time i za definiranje preferencija) ograničeni te je ovakvu pojavu nazvao "ograničena racionalnost" (Simon, 1955.). Ljudski um i razum kombinacija je razumnoga i strastvenoga, osviještenoga i neobjašnjivoga, a institucije i osjećaji pomažu čovjeku u njegovoj nesposobnosti savršeno racionalnog sagledavanja svih alternativa (Coase, 1984.). Glavna implikacija koncepta ograničene racionalnosti je da je ponašanje donositelja odluke uvjetovano višestrukim poticajima. Druga implikacija je da je prilagodba na te poticaje trenutna (Jones, 1999.). Ograničena racionalnost pretpostavlja da akteri u donošenju odluka imaju zacrtan cilj, ali za razliku od potpune racionalnosti, ograničena racionalnost uzima u obzir kognitivnu limitiranost.

Slikovitost nove perspektive institucionalne teorije ogleda se i u tome što pruža niz različitih pristupa ovisno autorima. Ipak, općenito gledajući tri su škole mišljenja koja većina autora prihvaća (Peters, 2007.; Hall i Taylor, 1996.): historijski institucionalizam, sociološki institucionalizam i pristup racionalnog izbora.

Naglasak u historijskom institucionalizmu stavljen je na razumijevanje i kontekstualno smještanje institucionalnih ograničenja u povijesni kontekst. Drugo, utjecaj tako oblikovanih ograničenja ogleda se u konačnom djelovanju grupe odnosno pojedinaca. Konačno, historijski institucionalisti smatraju kako odlučujuću ulogu prilikom odabira ishoda ili opredjeljenja imaju određene političke strukture koje definiraju i oblikuju ciljeve pojedinaca (Lalić Novak, 2014.). Historijski institucionalizam dijakronijski promatra institucije, istražujući kako okruženje utječe na nastanak institucije (Sewell, 2005.). March i Olsen kritiziraju bihevioriste smatrajući kako se institucije ne mogu analizirati isključivo kao posljedica individualnog ponašanja već su one sastavni dio društvenoga i političkoga života; March i Olsen tvrde kako društvo utječe na državu, ali i obratno (March i Olsen, 1984.). Historijski institucionalizam također proširuje definiciju institucije te ih objašnjava kao formalna pravila i postupke usklađenosti koji određuju odnos između pojedinaca u različitim područjima politike i gospodarstva, ali i kao neformalna pravila i procedure koje strukturiraju ponašanje (Thelen i Steinmo, 1998.).

Sociološki institucionalizam udaljava se od ideje o ograničenoj racionalnosti te radikalno negira koncept racionalizma. Sociološki institucionalizam, uz mnoga obilježja društvenog konstruktivizma, definira institucije u širem smislu, uključujući definiciju neformalnih i formalnih normi i konvencija (Nugent i sur., 1999.). Sociološki institucionalisti smatraju kako su usvojene institucionalne politike rezultat kulturnih specifičnosti i ceremonijalnih odrednica svojstvenih za pojedino društvo. Ključni koncept integriran u sociološki institucionalizam jest institucionalizacija; društveni proces u kojemu pojedinci prihvaćaju kolektivnu definiciju društvene stvarnosti te ju prihvaćaju "onakvu kakva jest" zanemarujući vlastita shvaćanja.

Promatrajući teoriju racionalnog izbora kroz institucionalnu teoriju postaje jasno kako jedna drugu međusobno nadopunjuju (Ostrom, 1998.); pretpostavke racionalnosti se nadilaze i promatra se utjecaj društveno konstruiranih uvjerenja, normi i pravila na orga- 
nizacijsko ponašanje (Scott, 2004.). Meyer i Rowan (1977.) odbacuju tvrdnju kako da organizacije racionalno usvajaju strukture, već su stava kako se primjenjuju institucionalizirani obrasci i strukture s ciljem postizanja i održavanja legitimnosti pritom je utjecaj na učinkovitost skoro pa marginaliziran. Pristup racionalnog izbora pretpostavlja kako su glavni akteri poslovnog (ili političkog) procesa pojedinci te djeluju racionalno kako bi maksimizirali svoju korist, a institucije utječu i oblikuju njihovo ponašanje (Lalić Novak, 2014.). Nadalje, postavka je da su pojedinci maksimizatori koristi koji slijede vlastite, osobne ciljeve koji su kombinacija zacrtanog skupa preferencija te raspolažu ekstenzivnim informacijama s time da je način interakcije i sam nastanak preferencije zanemaren.

Ovaj pristup analizira donošenje odluka pojedinaca unutar organizacije koji za cilj imaju maksimizirati korisnost unutar svoga okruženja (Scott, 2004.). Prediktira se da su donositelji odluka sposobni sustavno identificirati i odabrati optimalne alternative koristeći se pritom unaprijed definiranim kriterijima. Konkretna akcija se ne može promatrati kao izolirana cjelina već je ona dijelom cjelovitog društvenog sistema (Granovetter, 1985.) isprepletenog međuljudskim odnosima, a to upravo ovaj pristup zanemaruje; kontekstualnu dimenziju koja bi trebala služiti kao platforma za pružanje alternativnih scenarija. Teorija racionalnog izbora optimalno rješenje vidi kao kontinuirani proces pokušaja i pogreške u kojemu sudionici ne stječu nova znanja (Simon, 1997.). Pozadinska logika racionalnog izbora je da institucije zaista predstavljaju skup pravila i ograničenja koja određeno ponašanje potiču, a institucionalni akteri reagiraju na tako postavljene strukture. Međutim, preferencije aktera su ukorijenjene postavke te ostaju nepromijenjene bez obzira na institucionalno okruženje.

Unatoč diskrepanciji koju nudi institucionalna teorija pozivajući se na klasični i novi institucionalizam isto nužno ne sugerira njihovu isključivu dihtomiju. Ekstremna opredjeljenja u ovoj teoriji gotovo pa i nisu slučaj već su teoretičari i predstavnici prihvatili središnju putanju te usvojili ,ponajbolje od oba smjera“. Dobar dio pojmova vezanih uz formalističko poimanje društva i institucija poštuju i stari i novi institucionalisti. Rutherford (2001.) navodi kako individualisti uvažavaju činjenicu kako društvena cjelina duboko utječe na ponašanje pojedinca, s druge strane holisti se slažu da isključivo pojedinci, a ne institucije, mogu djelovati kao agenti promjena. Bihevioristi ne isključuju potpuno pristup racionalnog izbora te uvažavaju granice optimizacije suočavaju se s postavljanjem pravila od strane institucija. Ovako navedeno dovest će do zaključka kako suštinskih podloga za neslaganje gotovo i nema, međutim poanta je kako postavljene alternative nisu jednostavne za raščlanjivanje po principu ,crno-bijelo“.

\section{STRATEGIJA I STRATEŠKI PROCES IZ PERSPEKTIVE INSTITUCIONALNE TEORIJE}

Formalno izučavanje strateškog menadžmenta i strategije poduzeća započelo je osnivanjem odjela unutar (AoM) sedamdesetih godina 20. stoljeća te osnivanjem 1980. godine. Otprilike u istom tom razdoblju, interes za oživljavanjem institucionalne teorije doživio je svoj uzlet postajući tako dinamična i plodna teorijska perspektiva za izučavanje strategije poduzeća (Hambrick i Chen, 2008.). Institucionalna teorija analizira strategijske spoznaje kroz ograničenja koja potiču homogenost. Deephouseova (1999.) ideja o strateškoj ravnoteži 
pružila je optimalno viđenje strategije koje uključuje upravljanje pritiscima iz okoline, ali i orijentiranost diferencijaciji. Deephouse (1999.) je statistički prikazao stratešku ravnotežu kao stupanj devijacije od prosječne vrijednosti promatrajući određene atribute industrije. Zaključuje kako postoji značajni linijski odnos između srednje vrijednosti i devijacije gledajući konkretno poslovanje banaka i njihovih financijskih performansi te tvrdi kako teorija strateške ravnoteže može pomoći znanstvenicima u razumijevanju međuodnosa tržišne diferencijacije i usklađenosti s nametnutim propisima. Deephousovo otkriće kasnije se pokazalo kao dobra platforma za analizu organizacijskih performansi; prilikom istraživanja strateškog pozicioniranja (McNamara, Deephouse i Luce, 2003.), oponašanja konkurenata ili opredjeljenja za inovacije (Lieberman i Asaba, 2006.), istraživanja međuodnosa i interakcije menadžerskog uspjeha i konkurentskih podražaja, strateških saveza (Das i Teng, 2000.) i dinamike burzovnog poslovanja (Zott i Amit, 2007.).

Osim fokusa na istraživanje organizacijskih ishoda, institucionalna perspektiva u okvirima strateškog menadžmenta nastojala je objasniti sve dinamičniji odnos društvenih i kulturnih očekivanja te utjecaja na strateške odluke (Ingram i Silverman, 2002.). Legitimnost se postiže prihvaćanjem i usklađivanjem s dominantnim praksama u okvirima organizacijskog područja.

Homogenost strateškog procesa promatra se kroz povezanost organizacijske strukture i strateškog ponašanja (Hill i Hoskisson, 1987.). Osim toga, znanstvenici također bilježe sličan obrazac odabira organizacijske strukture unutar iste industrije. Odabrana struktura može se promatrati kao nulti strateški odabir koji implicira da se homogenost može promatrati i generalno u procesu donošenja strateških odluka. Provedena su istraživanja s ciljem dokazivanja kako organizacije svjesno i namjerno usvajaju strategije svojih konkurenata. Cool i Schendel (1988.) su istražujući američku farmaceutsku industriju dokazali kako se iste međusobno oponašaju i usvajaju slične strateške poteze. Willard (1985.) je promatrao strategije onih organizacija koje preživljavaju na tržištu i onih koje ne preživljavaju. Dokazao je sličnosti u strateškom ponašanju organizacija koje su preživjele, isto tako postojale su sličnosti među strategijama onih organizacija koje su propale te su se razlikovale od ovih prvih. Ovo istraživanje sugeriralo je kako opredjeljenje za oponašanjem strategije konkurenata može utjecati na cjelokupno organizacijsko poslovanje.

Pache i Santos (2010.) u svome istraživanju usvojenih strategija organizacija u polju promatraju broj usvojenih logika kao dijelom organizacijske funkcije i u kojoj mjeri je pojedina logika zastupljena. Ovisno o stupnju moći pojedinaca unutar organizacije, dodijeljeni su prioriteti logici koja će se odraziti na konačnu organizacijsku akciju; drugim riječima raspodjela moći utječe na ishod. Suprotno, ako je zastupljena samo jedna logika, ona će prevladati i bit će ugrađena u organizacijsko ponašanje i odlučivanje.

Homogenost u strateškim procesima promatra se kroz pojavu izomorfizma. Izomorfizam svojom ograničavajućom dimenzijom prisiljava određeni entitet unutar populacije da podsjeća na drugi entitet, ali promatran u istome okruženju i primjenjujući iste ili slične uvjete okoline. Pojava izomorfizma česta je u uvjetima kada organizacija stječe ili povećava kompatibilnost s drugim organizacijama u svojim okvirima djelovanja (Aldrich, 1979.; DiMaggio, Powell, 1983.; Fennell, 1980.). Promatrajući s razine strateškog procesa, razlikuju se dvije vrste izomorfizma: konkurentski izomorfizam i institucionalni izomorfizam. Institucionalna teorija pretpostavlja da pritisci okoline uvjetuju postizanje legitimnosti organizacijama bilo da se radi o usvajanju standardiziranih postupaka poslovanja, certificiranja 
ili regulatornih zahtjeva. Postizanje legitimnosti iz perspektive institucionalne teorije povećavaju šansu za opstanak organizacija. Obzirom na visoko strukturirano institucionalno okruženje koje u konačnici dovodi do formaliziranih pravila, s vremenom se smanjuje strateška raznolikost među organizacijama koje djeluju unutar iste industrije (Zucker, 1987.). Obzirom da je takvo okruženje splet međuodnosa organizacija koje kreiraju institucionalni kontekst, tako su i strateške akcije i strateške odluke ograničene, a nekada se nameću same po sebi. Logično, unaprijed nametnuti propisi i norme povećavaju vjerojatnost da će one organizacije unutar iste industrije koristiti i usvajati ista strateška rješenja. Homogenost strategije koju nudi institucionalna teorija promatra se kroz tri vrste izomorfizma: prinudni, mimetički i normativni.

\section{INSTITUCIONALNI IZOMORFIZAM: POJAM, VRSTE I RAZLOG IZUČAVANJA}

Institucionalna teorija kao središnji element postavlja institucionalni izomorfizam objašnjavajući ga činjenicom kako organizacije unutar svoga okruženja odnosno, organizacijskog polja, implementiraju one poslovne prakse i strukture koje se smatraju legitimnim i društveno prihvatljivim. Okruženje u kojemu organizacije djeluju implicira kako svaka organizacija nužno podliježe pritiscima koji iz njega proizlaze. Scott i Meyer (1991.) razlikuju koje suprotstavlja u međuodnos učinkovitost i odgovor na pritiske nametnute od strane samoga tržišta i usmjereno na proces postizanja legitimnosti i uzima u obzir društveni aspekt okruženja.

Osim sila konkurentske dinamike i društveno konstruirana uvjerenja, sustavi pravila i normi imaju značajnu kontrolnu ulogu nad organizacijama. Suvremeno izučavanje menadžerskih znanosti i organizacijske teorije u biti promatra širok spektar različitih i idiosinkratičnih organizacija te nastoji objasniti varijacije u organizacijskim formulacijama i ponašanju. Usprkos pretpostavkama heterogenosti kao preduvjetu uspješnosti uočljivo je kako je homogenizacijski trend u dobro uspostavljenim industrijama neizbježan. Neupitno je kako postoji interes za promatranje i objašnjavanje homogenosti među pojedinim organizacijama pogotovo ako se u obzir uzme činjenica kako u prvim fazama životnoga ciklusa organizacije pokazuju znatnu raznolikost u tržišnome nastupu, organizacijskome obliku i ponašanju, a uspostavljanjem stabilnih industrijskih uvjeta u kasnijim fazama ciklusa organizacije usvajaju slične ili gotovo iste strukture (Popadiuk, Rivera i Bataglia, 2014.). Iako organizacije usvajaju društveno racionalizirane strukture kako bi se smatrale legitimne to nužno ne implicira povećanje učinkovitosti i djelotvornosti praksi, a nerijetko tako usvojene strukture većinom budu ceremonijalnog karaktera i promatrane su kao mitovi. Legitimnost je izravna posljedica javnih politika i mijenja, razvijenosti obrazovnoga sustava, društvenoga statusa, zakonskih formulacija i sankcija (Meyer i Rowan, 1977.).

Homogenizacijski proces dovodi do zajedničkih i često sličnih organizacijskih struktura i procesa, a podliježe prisilnim, imitacijskim i normativnim pritiscima unutar istoga organizacijskog polja (DiMaggio i Powell, 1983.). Rezultat ovakvoga procesa je institucionalni izomorfizam, a podrazumijeva da organizacije $u$ istome organizacijskom polju tijekom vremena postaju slične; izomorfne. Institucionalna teorija je konceptom institucionalnog izomorfizma objasnila zašto organizacije unutar istoga organizacijskog polja pokazuju sličnosti u strukturnim obilježjima organizacijskih oblika. Predlaže da organizacije 
ne samo da moraju biti održive na konkurentnom tržištu, nego moraju također pokazivati strukturne oblike koji se u određenom institucionalnom okruženju smatraju legitimnima.

Sociološka perspektiva novoga institucionalizma potaknula je razmišljanje kako institucionalni izomorfizam više nije iznimka nego pravilo (DiMaggio, Powell, 1983.), a istim se pokušao objasniti homogenizacijski učinak koji izomorfizam ima na organizacijske strukture onih entiteta koji djeluju u istome organizacijskom polju. Hawley (1982.) je promatrao kako izomorfizam ponajprije ima ograničavajući učinak na organizacije prisiljavajući ih da nalikuju jedna na drugu jer se suočavaju s istim atributima u okruženju. Tandemi DiMaggio i Powell te Meyer i Rowan su homogenizacijski proces prihvatili kao početnu točku s time da ovi prvi kategorički raščlanjuju pritiske u okruženju koji kasnije dovode do tri oblika izomorfizma. Meyer i Rowan (1977.) su izomorfizam proučavali kroz dva oblika; konkurentski izomorfizam koji je nastao kao rezultat tržišnog natjecanja onih organizacija koje se suočavaju s istim uvjetima u polju. Međutim, ovaj oblik kritiziran je jer ne predstavlja realan prikaz i pogled na suvremenu organizaciju te su predstavili drugi oblik: institucionalni izomorfizam kojega su smjestili u kontekst okruženja i uvjeta pod kojime organizacije djeluju. Institucionalni izomorfizam objašnjava se kao organizacijsko nadmetanje nad političkim i institucionalnim legitimitetom, tržišnom pozicijom i društvenom dobrobiti (Bührman, 2011.).

DiMaggio i Powell u svome radu elaboriraju i nadopunjuju Meyerov i Rowanov prikaz institucionalnih mitova, čineći jasnu razliku između institucionalnih pritisaka. Uz konkurentski izomorfizam navode vrste i oblike institucionalnog izomorfizma opisujući ih kao prinudni, normativni i mimetički izomorfizam. Isti autori uočavaju kako se pojavni oblici institucionalnog izomorfizma i njegovi procesi primjećuju čak i ako oni nužno ne sublimiraju organizacijsku učinkovitost. Moguće poboljšanje učinkovitosti organizacije ogleda se u priznanju i naglašavanju sličnosti s ostalim uspješnim organizacijama u istome polju kako bi se olakšale transakcije i privlačio ljudski kapital. Takve organizacije priznate su kao legitimne, a uklapajući se u valjane administrativne definirane su kao podobne za poslovnu interakciju i sklapanje ugovora. Iako, uz sve navedeno, nema empirijskih dokaza da su one organizacije koje su usklađene s uvjetima proizašlim iz izomorfističkog djelovanja učinkovitije od ostalih.

Polazeći od analize organizacijskog polja kao arene djelovanja i interakcije organizacija s dobavljačima, potrošačima i regulatornih agencija kako ju predlažu DiMaggio i Powell usmjerava se istraživanje na sve relevantne čimbenike organizacijskog polja čiji ekonomski poredak nije uvijek i nužno pozitivno koreliran s izvorom moći. Prema tome, oformljene organizacije koje već egzistiraju u suvremenom društvu postaju homogene zbog procesa interakcije s ostalim dionicima polja, a taj proces nazivaju izomorfizam koji se javlja unutar specifičnog konteksta koji se sada naziva organizacijsko polje te intencije za racionalno suočavanje s neizvjesnosti u okruženju u konačnici dovode do homogenih struktura, nerijetko i homogenih konačnih rješenja. Nesigurnost odnosno neizvjesnost u okruženju može se promatrati kao relevantna potisna sila koja potiče imitaciju među organizacijama. Organizacije oblikuju svoje strukture, ali i ponašanje u odnosu na ostale organizacije kada se pojave nova tehnološka rješenja i tehnologija koju nisu sasvim razumjele ili kada su ciljevi dvosmisleno postavljeni.

Svrhovitost izučavanja institucionalnog okruženja proizlazi iz kognitivnih paradigmi ponašanja koje su prihvaćene „zdravo za gotovo“ te teorijski opisuju i analiziraju učinak 
odnosa organizacija i okruženja, i s druge strane, normativnih okvira koji uključuju pretpostavke o vrijednostima, stavovima, identitetima i ostalim ,zajedničkim uvjerenjima“ čime je raspon alternativa drastično sužen (Miller i Banaszak-Holl, 2005.). Organizacije usvajaju institucionalno povlaštene karakteristike kroz slične strukture, postupke i/ili prakse kroz tri mehanizma odnosno načina (DiMaggio, Powell, 1983.): prinudni, normativni i mimetički izomorfizam.

Prinudni izomorfizam nastaje kao posljedica institucionalnih pritisaka od strane organizacija na one organizacije koje ovise o njima (DiMaggio i Powell, 1983.). U prvi plan ovdje su stavljeni formalni i neformalni pritisci od strane države, zakonodavnih tijela, regulatornih agencija, ali i kulturalnih očekivanja koje društvo ima od organizacije (Tipurić, 2014.).

Normativni izomorfizam rezultat je profesionalizacije unutar određenog organizacijskog polja (Tipurić, 2014.; Johnston, 2013.). Profesionalizacija se definira kao kolektivni napor pripadnika iste profesije s ciljem uspostavljanja pravila i ograničenja koja reguliraju metode i način rada u toj profesiji i postavljanja kognitivnih osnova njihove autonomije (Ashworth i sur., 2009.). Pojedinci unutar profesionalnih skupina razvijaju kroz specijalizirane edukacije običaje i norme koje se povezuju s njihovom profesijom. Kao posljedica navedenoga, pojedinci koje povezuje ista profesija tijekom vremena će razviti homogene vještine i karakteristike s ciljem stjecanja legitimnosti.

Mimetičkim izomorfizmom (DiMaggio i Powell, 1983.) označava se postupak "preslikavanja" i usvajanja praksi i struktura one organizacije za koju ostale smatraju da su uspješnije i legitimnije. Organizacije imaju tendenciju oblikovanja svojih praksi i politika imitirajući one organizacije za koje smatraju da su uspješne i legitimne. Mimetički izomorfizam posljedica je nesigurnosti u okruženju i nejasnih organizacijskih ciljeva. Organizacija koju se oponaša nerijetko nije svjesna da biva oponašana, međutim za drugu stranu ona je vrijedan izvor ideja koje će primijeniti na vlastito poslovanje.

Dosadašnja istraživanja institucionalnog izomorfizma u menadžerskim i organizacijskim znanostima, orijentirana su uglavnom prema istraživanju utjecaja mimetičkog izomorfizma na određenu pojavu u poslovnoj praksi. Tseng i Chou (2011.) su u svome istraživanju promatrali 11 akvizicija i pripajanja tajvanskih financijskih organizacija pri čemu su kao zavisnu varijablu koristili organizacijske performanse u postupcima akvizicija. Zaključuju kako je prijašnje iskustvo u području akvizicija i pripajanja pozitivno korelirano s budućim ishodima ponavljanja ovih pothvata. Barreto i Baden-Fuller (2006.) istražuju banke u Portugalu odnosno odluke vezane uz osnivanje podružnica; zaključuju kako banke oponašaju one skupine organizacija s kojima dijele iste atribute pogotovo u dijelu postizanja legitimnosti čak i kada imitacija umanjuje profitabilnost.

\section{ZAKLJUČNE MISLI}

Uvažavajući poliperspektivizam discipline strateškog menadžmenta, teorijski pristup institucionalne teorije organizacije nedovoljno je istražen u stranoj literaturi dok je u domaćoj gotovo zanemaren. Motiv za istraživanje institucionalne teorije organizacije i institucionalnog izomorfizma nameće se kao logičan potez obzirom na dosad (ne)provedena istraživanja. 
Ovim radom otvara se prostor za buduća istraživanja područja koja su dosad bila u sjeni mnogo popularnijih i atraktivnijih pristupa poput kontingencijske teorije, agencijske teorije i resursnog pristupa strategiji. Usmjeravanje fokusa na promatranje strateškog menadžmenta iz perspektive institucionalne teorije predstavlja bitan iskorak u promatranju strategije poduzeća koja svoje temelje, u ovome slučaju ne postiže kombinacijom jedinstvenih resursa, već sposobnošću da oblikuje i prilagodi svoje ponašanje unutar zadanih okvira nametnutih od strane institucija.

Koncept institucionalnog izomorfizma i institucionalne teorije gotovo da je zanemaren u domaćoj literaturi, a značaj navedenih konstrukata u poslovnoj praksi je nepobitan. Institucionalna teorija i njezin ključni argument institucionalni izomorfizam relativno su mlade teorijske perspektive koje omogućavaju razumijevanje pojava i poslovnih procesa kroz strukturu i performanse suvremenih organizacija s ciljem postizanja legitimnosti koje ostale teorije ne nude.

Iako institucionalna teorija tek čeka svoj uzlet i prodor u relevantnu literaturu, ovaj pristup konceptualno značajno pridonosi razumijevanju dinamike organizacija. Istraživanja temeljena na racionalističkim objašnjenjima organizacijskog ponašanja preusmjerena su prema prepoznavanju da su organizacijsko ponašanje i organizacijski procesi dio kulturnoga i političkoga konteksta. Nadalje, suština jest da fokus nije objasniti heterogenost među organizacijama, već upravo suprotno; dokazivanje njihove sličnosti.

\section{LITERATURA:}

1. Aldrich, H. (1979). Organizations and environments. Englewood Cliffs: Prentice-Hall.

2. Ashworth, R., Boyne, G., Delbridge, R. (2009). Escape from the Iron Cage? Organizational Change and Isomorphic Pressures in the Public Sector. Journal of Public Administration Research and Theory, 19 (1) 165-187.

3. Barreto, I., Baden-Fuller, C. (2006). To Conform or To Perform? Mimetic Behaviour, Legitimacy-Based Groups and Performance Consequences. Journal of Management Studies, 43 (7), 1559-1581.

4. Bührman, G. (2011). Institutional Pressures and Strategic Responses: The Case of the BP Oil Spill (Magistarski rad).Strategy \& Organization, Amsterdam.

5. Coase, R. H. (1984). The New Institutional Economics. Journal of Institutional and Theoretical Economics, 140 (1), 229-231.

6. Cool, K., Schendel, D. (1988) Performance differences among strategic group members. Strategic Management Journal, 9, 207-223.

7. Das T. K, Teng B. S. (2000). Instabilities of strategic alliances: an internal tensions perspective. Organization Science, 11 (1), 77-101.

8. Deephouse D. L. (1999). To be different, or to be the same? It's a question (and theory) of strategic balance. Strategic Management Journal, 20 (2), 147-166.

9. DiMaggio, P. J., Powell, W. W. (1983). The Iron Cage Revisited: Institutional Isomorphism and Collective Rationality in Organizational Fields. American Sociological Review, 48, 147-160. 
10. Fennell, M. (1980). The effects of environmental characteristics on the structure of hospital clusters. Administrative Science Quarterly, 25, 484-510.

11. Granovetter, M. (1985). Economic action and social structure: the problem of embeddedness. American Journal of Sociology, 91 (3), 481-510.

12. Hall, P. A., Taylor, R. C. A. (1996). Political science and the Three New Institutionalism. Political studies, 44, 936-957.

13. Hambrick D. C., Chen M. J. (2008). New academic fields as admittance-seeking social movements: the case of strategic management. Academy of Management Review. 33 (1), 32-54.

14. Hawley, A. (1968). Human Ecology. u Sills, D. L., International Encyclopaedia of the Social Sciences. New York: Macmillan.

15. Hill, C., Hoskisson, R. (1987). Strategy and structure in the multiproduct firm. Academy of Management Review, 12, 331-341.

16. Hirsch, P. M. (1997). Ending the Family Quarrel: Towards a Reconciliation of "Old" and "New" Institutionalism. American Behavioural Scientist, 40, 406-18.

17. Ingram P, Silverman B. S. (2002). The new institutionalism in strategic management. Advances in Strategic Management, 19, 1-30.

18. Johnston, M (2013). Mimetic, Coercive and Normative Influences and the Decision of National Sport Organisations to Bid for World Championship Events (Magistarski $\mathrm{rad})$, Auckland University of Technology: New Zealand.

19. Jones, B. D. (1999). Bounded rationality. Annual review of Political Science, 2, 297-321.

20. Lalić Novak, G. (2014.). Institucionalizacija organizacijskog polja i utjecaj institucionalne logike upravnog sustava na prijenos i interpretaciju pravila polja: azil kao studija slučaja. Hrvatska i komparativna javna uprava: časopis za teoriju i praksu javne uprave, 13 (4), 1031-1060.

21. Lieberman M. B, Asaba S. (2006). Why do firms imitate each other?. Academy of Management Review, 31 (2), 366-385.

22. March, J. G., Olsen, J. P. (1984). The New Institutionalism: Organizational Factors in Political Life. American Political Science Review, 78, 738-749.

23. McNamara G., Deephouse D. L, Luce R. A. (2003). Competitive positioning within and across a strategic group structure: the performance of core, secondary and solitary firms. Strategic Management Journal, 24 (2), 161-181.

24. Meyer, J. W., Rowan, B. (1977). Institutionalized Organizations: Formal Structure as Myth and Ceremony. American Journal of Sociology, 83 (2), 340-363.

25. Miller, E. A., Banaszak-Holl, J. (2005). Cognitive and normative determinants of state policymaking behaviour: Lessons from the sociological institutionalism. Publius, 35 (2), 191-216.

26. North, D. C. (2003). Institucije, institucionalna promjena i ekonomska uspješnost. Zagreb: Masmedia.

27. Nugent, B. J., Campos, N. F. (1999). Development Performance and the Institutions of Governance: Evidence from East Asia and Latin America. World Development, 27 (3), 439-452. 
28. Nugent, N., Cram, L. I Des, D. (1999). Reconciling theory and practice: Developments in the European Union. London: Macmillan.

29. Ostrom, E. (1998). A behavioural approach to the rational choice theory of collective action: Presidential address. The American Political Science Review, 92 (1), 1-22.

30. Pache, A., Santos, F. (2010). When worlds collide: The internal dynamics of organizational responses to conflicting institutional demands. Academy of Management Review, 35(3), 455-476.

31. Peters, B. G. (2007). Institutional theory in political science: The „new institutionalism“. London: Pinter.

32. Popadiuk, S., Rivera, E. R., Bataglia, W. (2014). Heterogeneity of Isomorphic Pressures: Intertwining the Resource-Based View and the Neoinstitutional Approach. Brazilian Administration Review, 11(4), 455-475.

33. Rutherford, M. (2001). Institutional economics: then and now. Journal of Economic Perspectives, 15 (3), 173-194.

34. Scott, R. W. (2008) Approaching adulthood: The maturing of institutional theory. Theory and Society, 37 (5), 427-442.

35. Scott, W. R. (2001). Institutions and Organizations. 2nd edition. Thousand Oaks: Sage.

36. Scott, W. R. (2004). Institutional Theory: Contributing to a Theoretical Research Program. Oxford: Oxford University Press.

37. Scott, W. R., Meyer, J. W. (1991). The organization of societal sectors: propositions and early evidence. u Powell, W. W., DiMaggio, P (Ur.) The new institutionalism in organizational analysis. Chicago: University of Chicago Press.

38. Sewell, W. (2005). Logics of History. Chicago: University of Chicago Press.

39. Simon, H. A. (1955). A Behavioural Model of Rational Choice. The Quarterly Journal of Economics, 69 (1), 99-118.

40. Simon, H. A. (1997) Administrative Behaviour: A Study of Decision-Making Processes in Administrative Organizations 4th ed. New York: Basic Books.

41. Thelen, K., Steinmo, S. (1998). Structuring politics: Historical institutionalism in comparative analysis. Cambridge: Cambridge University Press.

42. Tipurić, D. (2014.). Iluzija strategije, Zagreb: Sinergija.

43. Tseng, J. J., Chou, P. H. (2010). Mimetic isomorphism and its effect on merger and acquisition activities in Taiwanese financial industries. The Service Industries Journal, 31 (9), 1451-1469.

44. Veblen, T. (1899). The Theory of the Leisure Class. New York: The Macmillan Company.

45. Willard, G. (1985). Survivors of industry shakeouts: The case of the U.S. colour television industry. Strategic Management Journal, 6, 299-318.

46. Zott C, Amit R. (2007). Business model design and the performance of entrepreneurial firms. Organization Science 18(2): 181-199.

47. Zucker, L. (1987). Institutional theories of organization. Annual Review of Sociology, 13, 443-464. 